\title{
A short primer on transplant tourism
}

\author{
Saad Ahmed (Meds 2016) \\ Faculty Reviewer: Dr. Faisal Rehman, MD, FRCPC, M.Ed (Department of Medicine, Division of Nephrology), \\ Dr. Nelson Chan, MD, LL.B, CCFP (Department of Family Medicine)
}

$\mathrm{M}$ ale, 45 years old, presenting with severe sepsis - rushed in straight from the airport. On further investigation the patient also has an inflamed incision lateral to their upper right abdominal quadrant that seems infected. The family seems tight-lipped about the details of the trip, but on pressing they mentioned a kidney transplant done abroad as the reason.

What do you do in this situation?

\section{INTERNATIONALLY:}

In 2008 delegates from all around the world drafted the Istanbul Declaration. It explicitly stated that organ trafficking and commercialism exploits the poor and should be completely banned. ${ }^{1}$ Whereas organ trafficking is done with coercion and usually violence, even organ commercialism involves a certain amount of monetary coercion, especially since there are power asymmetries between someone in a developed country and a desperately poor person in a developing country. ${ }^{1}$ Those who are forced to sell their kidneys as a result of financial hardships frequently report that they are left frail and sick, with the money disappearing in no time. ${ }^{2}$ Secondly, multiple studies from Canada, the US, and Australia have shown that the health outcomes of transplants tourists are significantly worse than patients who received their transplants domestically and legitimately.

The policy makers at the Istanbul Declaration recognized that organ trafficking and commercialism is ultimately driven by demand from people in developed countries who are suffering on organ recipient waitlists. To this end, they reinforced the importance of policies that increase domestic organ donation rates, ${ }^{i}$ some of which have been adopted in Canada. An example of these policies being put into practice is the Living Donor Paired Exchange (LDPE) Registry, a national registry for patients suffering from chronic kidney disease, and the Living Organ Donor Reimbursement Program (LODRP), which has been adopted in at least 5 provinces. The LODRP reimburses organ donors for various expenses and time lost throughout the process of donation and recovery. The LDPE matches transplant patients who have incompatible living donors with each other - the idea being that one patient's incompatible donor may be compatible with another patient, whose living donor may be compatible with the former patient. It has been shown to increase organ donations by up to $10 \% .^{3}$

The Declaration has had significant influence globally - especially in countries formerly considered to be hotbeds of organ trafficking and commercialism, such as China, Pakistan and the Philippines. Legislation is now in place to prohibit the practice. ${ }^{4}$ Countries are also working together to apprehend and charge those who continue to participate in organ trafficking. For instance, European and Canadian authorities in Kosovo recently dismantled an infamous organ trafficking ring spread out across three continents; and a criminal trial has begun to sentence the traffickers. ${ }^{2}$

\section{DOMESTICALLY:}

In Canada, the Canadian Society of Transplantation and the Canadian Society of Nephrology jointly released a policy statement on organ trafficking and transplant tourism. In their preamble, they affirmed the principles of the Istanbul Declaration ${ }^{5}$ and a physician's duty to never deny care to a patient. The main crux of the policy statement is focused on preventing people from undergoing transplant tourism in the first place. ${ }^{4}$ The myriad problems and complications of transplant tourism should be coherently communicated to patients - such as the difficulty in receiving insurance coverage for long-term anti-rejection medications due to the lack of documentation and unethical nature of the transplant. ${ }^{4}$ To this end, the Kidney Foundation of Canada released a set of pamphlets that warns people about the possible consequences of transplant tourism (see http://www.kidney.ca/document.doc?id=1239).

The data from a single centre study which looked at 93 transplant tourists from British Columbia, affirms the need for thorough and proper pre-transplant counseling. ${ }^{6}$ The study found that $30 \%$ of the respondents had never been referred for a transplant consult, and had thus preemptively undergone a kidney transplant. Another $33 \%$ of the transplant tourists in the study had completed a transplant consult, and after being waitlisted for a transplant sought a commercial transplant. This speaks to a need for a multi-faceted policy. If $30 \%$ of transplant tourists are pre-emptively receiving transplants without an actual referral after the development of end-stage renal disease, it speaks to a need for public campaigns discouraging transplant tourism, as well as a need to educate patients before the development of end-stage renal disease. Secondly, other patients received a referral, but failed to follow up and were lost to the system - hence the study mentions that patients must be tracked better. Furthermore, considering that the vast majority of transplant tourists were ethnic minorities, ${ }^{5}$ the study argued that outreach efforts must be made to members of these communities to discourage transplant tourism. And for the $33 \%$ of patients who had gone abroad for a transplant after being put on a waitlist, the study advocated for policies such as the Paired Living Donor Exchange Registry. Studies held in centres across the US and Australia had similar findings and recommendations. ${ }^{7,8,9}$

Numerous public health problems have been raised by a Canadian study of transplant tourists. ${ }^{10}$ There have been cases of patients presenting with multiple drug-resistant Escherichia coli, active tuberculosis, as well as other viruses and fungal infections not typically seen in Canada. The presence of multiple drug resistant bacteria certainly poses a domestic public health concern.

\section{LEGALLY \& SOME DEFINITIONS:}

Under Section 279.04 of the Criminal Code of Canada, it is a criminal 


\section{ETHICS AND LAW}

offence to exploit another person and by the use of force, deception, or coercion remove their organs or tissues - be it domestically or internationally. ${ }^{11,12}$ There is however currently no overarching federal law prohibiting Canadians from obtaining commercial organ transplants overseas, which were sold by a consensual donor. ${ }^{13,14}$ In 2009, the House of Commons nearly passed Bill C-381 into law. ${ }^{15}$ It sought to explicitly prohibit Canadians from going abroad to purchase an organ and would have criminalized any sort of participation, even indirect, in organ trafficking or transplant commercialism.

Bill C-381 would have also required health care professionals to report any patients of theirs who had undergone transplant tourism, much akin to mandatory reporting mechanisms already in place. ${ }^{16}$ Some academics argue that simply banning this practice will not work. ${ }^{4}$ To control an industry that has been roughly estimated to generate $\$ 600$ million to $\$ 1.2$ billion a year $^{3}$ in profits will be difficult, especially when a market of desperately ill and desperately poor people continues to exist. They contend that organ scarcity, which drives demand, needs to be dealt with by increasing organ donation via policies such as offering incentives for donation. However, it is hard to extrapolate these academics' arguments further, as it would otherwise lead to the unjustifiable position of allowing transplant tourism in some shape or form.

\section{CONCLUSION:}

Fundamentally, the issue of organ transplantation and commercialism is one of desperation-driven demand. Physicians should ensure that their patients understand the severe and frequent side effects of transplant tourism. They should explain the heinous facts - the various criminal organizations that the transplant trade funds, and the incredibly unethical nature of the trade, which is nothing short of the exploitation of the poor. These perils must be communicated early, before organ failure, so that patients do not act out of desperation. And if a patient with a commercial transplant comes into their care, they must simply remember their duty to minimize the patient's suffering and provide the best possible care for them.

The stakes are nothing more than the lives of the most vulnerable and distressed individuals in our communities and around the world.

\section{REFERENCES:}

1. International Summit on Transplant Tourism and Organ Trafficking. The Declaration of Istanbul on Organ Trafficking and Transplant Tourism. Clin J Am Soc Nephrol. 2008 Sep;3(5):1227-31.

2. Sher J. Toronto man who bought kidney abroad is key witness in transplant sale trial in Kosovo [Internet]. Toronto Star; 2012 Jan 22 [Cited 2013, Feb 18]. Available from: http://www.thestar.com/news/ canada/article/1119337--toronto-man-who-bought-kidney-abroad-iskey-witness-in-transplant-sale-trial-in-kosovo

3. Ferrari P, de Kierk, M. Paired kidney donations to expand the living donor pool. J Nephrol. 2009 Nov-Dec; 22(6):699-707.

4. Ambagtsheer F, Weimar W. A Criminological Perspective: Why Prohibition of Organ Trade Is Not Effective and How the Declaration of Istanbul Can Move Forward. Am J Transplant. 2012 Mar; 12(3):571-5.

5. Gill JS, Goldberg A, Prasad GV, Fortin MC, Hansen TB, Levin A, Gill J, Tonelli M, Tibbles LA, Knoll G, Cole EH, Caulfield T. Policy Statement of Canadian Society of Transplantation and Canadian Society of Nephrology on Organ Trafficking and Transplant Tourism. Transplantation. 2010 Oct 27; 90(8):817-20.

6. Gill J, Diec O, Landsberg DN, Rose C, Johnston O, Keown PA, Gill JS. Opportunities to deter transplant tourism exist before referral for transplantation and during the workup and management of transplant candidates. Kidney Int. 2011 May;79(9):1026-31.

7. Kennedy SE, Shen Y, Charlesworth JA, Mackie JD, Mahony JD, Kelly JJ,
Pussell BA. Outcome of overseas commercial kidney transplantation: an Australian perspective. Med J Aus. 2005 Mar 7;182(5):224-7.

8. Canales MT, Kasiske BL, Rosenberg ME. Transplant tourism: outcomes of United States residents who undergo kidney transplantation overseas. Transplantation. 2006 Dec 27; 82(12):1658-61.

9. Gill J, Madhira BR, Gjertson D, Lipshutz G, Cecka JM, Pham PT, Wilkinson A, Bunnapradist S, Danovitch GM. Transplant tourism in the United States: a single-center experience. Clin J Am Soc Nephrol. 2008 Nov; 3(6):1820-8.

10. Prasad GV, Shukla A, Huang M, D’A Honey RJ, Zaltzman JS. Outcomes of Commercial Renal Transplantation: A Canadian Experience. Transplantation. 2006; 82 (9), 1130-1135.

11. Criminal Code of 1985, R.S. c. C-46 [Internet]. Available from: http:// laws.justice.gc.ca/en/C-46/index.html

12. An Act to amend the Criminal Code (trafficking in persons), S.C. 2012, c. 15 [Internet]. Available from: http://laws-lois.justice.gc.ca/eng/AnnualStatutes/2012 15/page-1.html

13. Christian L. Human Trafficking and Selling your Own Organs in Canada [Internet]. Ottawa (ON): Law office of Lisa Christian; 2012, Nov 09 [cited 2013, Feb 18). Available from: http://christiancriminallawottawa.com/ blog/230-human-trafficking-and-selling-your-own-organs.html

14. Canadian laws lax on sale of organs, says transplant expert [Internet]. CBC News; 2008 Jan 31 [Cited 2013, Feb 18]. Available from: http://www. cbc.ca/news/health/story/2008/01/31/bc-canada-lax-on-organ-trade. $\underline{\text { html }}$

15. Sher J. Transplant tourism a form of cannibalism [Internet]. Toronto Star; 2012, Jan 22 [Cited 2013, Feb 18]. Available from: http://www.thestar. com/news/canada/article/1119338--transplant-tourism-a-form-ofcannibalism

16. Chan C. Canadian MP Re-introduces Bill to Curb 'horrific' Organ Trade [Internet]. Epoch Times. 2009, May 13 [Updated 2009, May 14; cited 2013 Feb 18]. Available from: http://www.theepochtimes.com/n2/world/canada-

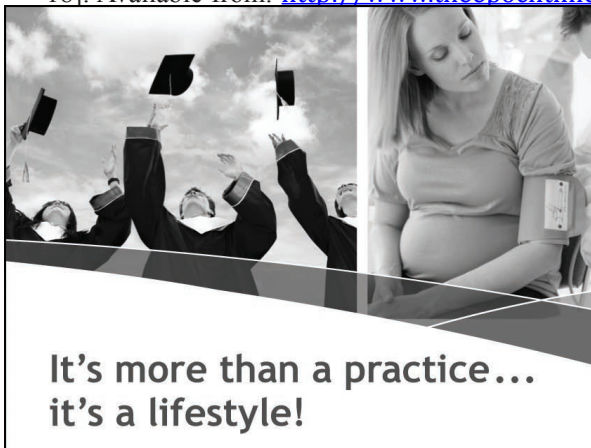

General Practice and Specialty opportunities available in Northern British Columbia.

Join a progressive medical team and live in the most beautiful place in Canada. Northern British Columbia is a region graced with a diverse natural beauty found nowhere else on earth. At Northern Health, we are proud to be a state-of-the-art, integrated health care provider, caring for a population of over 300,000 across Northern British Columbia.

Come talk to us!

We invite you to consider a personal and professional adventure and to discover the benefits of a front-line health care practice in an extraordinary setting. We offer a progressive and consultative work culture as well as leading relocation assistance.

\section{Start your life and your practice in Northern BC!}

Please call 1.877.905.1155 or visit our website to find out all that our region and organization has to offer and how to make the most exciting move of your life. careers.northernhealth.ca

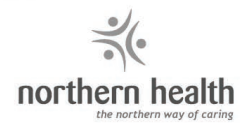

